\title{
PENINGKATAN KEMAMPUAN SERAPAN NITROGEN (N) TANAMAN PADI (Oryza sativa L.) MELALUI MUTASI GEN SECARA KIMIAWI
}

\author{
Improvement of Nitrogen (N) Implementation Capability in Rice Plant \\ (Oryza sativa L.) by Chemical Mutation \\ Khoirotun Nikmah $^{1) *}$, Miswar Musni ${ }^{1)}$ \\ 1) Agroteknologi, Fakultas Pertanian, Universitas Jember \\ ")e-mail: khoirotunnikmah009@gmail.
}

\begin{abstract}
ABSTRAK
Tanaman padi adalah salah satu tanaman pangan yang memiliki nilai penting bagi masyarakat Indonesia. Penggunaan pupuk nitrogen $(\mathrm{N})$ dalam kegiatan budidaya padi meningkat setiap tahun, tetapi kemampuan tanaman padi untuk menyerap unsur $\mathrm{N}$ masih rendah, sekitar $30 \%-50 \%$ dan kehilangan $\mathrm{N}$ ke lingkungan tanah juga cukup tinggir. Upaya untuk mendapatkan varietas padi yang memiliki kemampuan tinggi dalam menyerap $\mathrm{N}$ dapat dilakukan melalui mutasi buatan menggunakan senyawa kimia, salah satunya menggunakan Ethyl Methane Sulfonate (EMS). Penelitian ini dapat memberikan informasi tentang pengembangan varietas padi baru yang memiliki tingkat penyerapan $\mathrm{N}$ yang tinggi, sehingga dapat meningkatkan pertumbuhan dan produksi tanaman ini. Padi yang telah dimutasi dan dikendalikan kemudian dikecambahkan dalam media tanam pasir dan ditanami secara hidroponik dengan diberi nutrisi. Setiap 10 hari sampel nutrisi pada media tanam dan dilakukan pengukuran tanaman tinggi. Pengambilan sampel nutrisi diambil dari 4 titik pada masing-masing tanaman kemudian sampel ditambahkan dengan $\mathrm{NO}_{3}$ - dan $\mathrm{NH}_{4}{ }^{+}$berdasarkan metode Cataldo et al., (1975) untuk kandungan nitrat dan amonium menggunakan Baethgenand Alley (1989).
\end{abstract}

Kata kunci: Padi, mutasi gen, EMS (Ethyl Methane Sulfonate), penyerapan N

\section{ABSTRACT}

Rice plants are one of the food crops that have important values for the people of Indonesia. The use of nitrogen fertilizer $(N)$ in rice cultivation activities increases every year, but the ability of rice plants to absorb non- $N$, is still small, around 30\% $-50 \%$ and spending $N$ on the soil is also quite large. Efforts to obtain rice varieties that have high ability to combine cannot be done through artificial mutations using chemical composition, one of which uses Ethyl Methane Sulfonate (EMS). This study discusses the results of research on the ability to combine nitrogen nutrients by plants and it is hoped that this research can provide information about the development of new varieties of rice that have high levels of demand, so as to increase the growth and production of these plants. Rice that has been mutated and controlled is then germinated in sand planting media and planted with hydroponics by being given nutrients. Every 10 days a sample is taken of nutrients taken on the growing media and measurements of tall plants are carried out. The taking of nutrient samples was taken from 4 points on each plant then the samples were added with NO3-and NH4 + based on the Cataldo et al., (1975) method for nitrate and ammonium content using Baethgen and Alley (1989).

Keywords: rice, gen mutation, EMS (Ethyl Methane Sulfonate), $N$ absorption

\section{PENDAHULUAN}

Tanaman padi (Oryza sativa L.) merupakan salah satu tanaman pangan yang memiliki nilai penting, karena $90 \%$ dari keseluruhan penduduk Indonesia menjadikan 
beras sebagai makanan pokok sehari-hari. Beras menyediakan sekitar $21 \%$ dari total kalori pangan bagi penduduk dunia, terutama penduduk Asia termasuk Indonesia (Saragih, 2001). Kebutuhan beras setiap tahunnya selalu mengalami suatu peningkatan seiring bertambahnya jumlah penduduk, sehingga diharapkan produksi padi setiap tahunnya dapat meningkat.

Penggunaan pupuk nitrogen $(\mathrm{N})$ dalam kegiatan budidaya tanaman padi setiap tahun mengalami peningkatan, tetapi kemampuan tanaman padi untuk menyerap unsur $\mathrm{N}$ masih rendah, yaitu sekitar 30\%-50\%, sisanya (50-70\%) akan hilang ke lingkungan. Kehilangan unsur $\mathrm{N}$ yang tinggi dapat disebabkan oleh denitrifikasi, pelindian, volatilisasi, dan tercuci oleh aliran permukaan. Umumnya unsur hara nitrogen tersebut yang dapat diserap oleh akar tanaman berupa nitrat $\left(\mathrm{NO}_{3}{ }^{-}\right)$dan amonium $\left(\mathrm{NH}_{4}^{+}\right)$,

Unsur hara nitrogen $(\mathrm{N})$ berperan penting bagi tanaman, khususnya untuk pertumbuhan dan produksi tanaman. Unsur $\mathrm{N}$ juga berperan sebagai molekul signal yang mengatur proses-proses fisiologi dan perkembangan yang penting, selain sebagai nutrisi bagi tanaman (Bouguyon et al., 2012). Tanaman dalam proses penyerapan unsur $\mathrm{N}$ dari tanah difasilitasi oleh protein transporter yang terdapat pada bagian membran sel akar. Pengaturan metabolisme $\mathrm{N}$ pada tanaman merupakan proses yang bertautan dan dipengaruhi oleh beberapa proses fisiologi dan metabolit, seperti sintesis sukrosa, proses transport, $\mathrm{N}$ metabolit glutamin dan $\mathrm{NO}_{3}{ }^{-}$(López-Arredondo et al., 2013).

Kemampuan penyerapan unsur N (nitrat dan amonium) oleh tanaman padi diatur secara komplek. Perbaikan genetik terhadap kemampuan menyerap $\mathrm{N}$ dan efisiensi penggunaan $\mathrm{N}$ oleh tanaman padi memberikan sumbangan besar, terutama untuk mengurangi penggunaan pupuk $\mathrm{N}$ dan kerusakan lingkungan akibat pencemaran nitrat (Matsunami et al., 2013). Salah satu upaya yang dilakukan dalam kegiatan pemuliaan tanaman untuk perbaikan genetik dan menghasilkan keragaman genetik yang tinggi yaitu dengan induksi mutasi. Perbaikan genetik melalui mutasi menggunakan senyawa kimia akan mengubah proses metabolisme pada keseimbangan yang baru yang mendukung metabolisme N, sehingga dapat meningkatkan pertumbuhan dan produksi. Senyawa kimia yang digunakan untuk melakukan mutasi pada tanaman antara lain Ethyl Methane Sulfonate (EMS) dan sodium azid (SA) (Wei et al., 2013).

Berdasarkan masalah di atas, perlu diketahui sejauh mana respon tanaman padi hasil mutasi terhadap kemampuan tanaman dalam menyerap unsur hara nitrogen serta pengaruhnya terhadap pertumbuhan dan produksi tanaman. Oleh karena itu perlu dilakukan sebuah penelitian yang tujuannya adalah untuk mengetahui respon tanaman padi hasil mutasi dengan menggunakan bahan kimia EMS terhadap pertumbuhan dan 
perkembangan tanaman, sehingga diharapkan hasil produksi padi akan meningkat seiring dengan meningkatnya kemampuan serapan unsur hara $\mathrm{N}$ tersebut.

\section{METODE PENELITIAN}

Alat-alat yang digunakan dalam penelitian ini yaitu gelas ukur, penggaris, spektrofotometer, bak pengecambah, sekop, pot, sprayer, inkubator, gelas beker, tabung reaksi, eppendorp, pipet volume, bulb, corong gelas, kaca pengaduk, dan neraca analitik.

Bahan yang digunakan dalam penelitian ini yaitu benih padi varietas ciherang, aquades, larutan EMS, pasir, dan larutan nutrisi, salicylic acid, $\mathrm{H}_{2} \mathrm{SO}_{4}, \mathrm{NaOH}$, nitropruside, larutan buffer, dan larutan hipoklorid.

Mutasi Benih dilakukan dengan pembuatan larutan stok EMS 0.7\% dibuat dengan cara mengambil larutan EMS sebanyak $175 \mu$ menggunakan mikropipet lalu diencerkan dengan menambah larutan aquadest sebanyak $25 \mathrm{ml}$. Sebelum dilakukan mutasi, benih padi direndam ke dalam $100 \mathrm{ml}$ aquadest pada suhu ruang selama 24 jam. Benih yang telah direndam dikeringkan diatas kertas saring. Benih yang digunakan untuk kontrol hanya direndam dengan aquadest, sedangkan pada perlakuan mutasi benih direndam dalam larutan EMS konsentrasi 0,7\% selama 6 jam dan dilakukan pengocokan secara berkala setiap 1 jam. Benih yang telah direndam kemudian dibilas dengan air mengalir dan selanjutnya benih dikeringkan terlebih dahulu sebelum ditanam.

Benih hasil mutasi dan kontrol (tidak dimutasi) dikecambahan pada bak perkecambahan dengan media pasir selama 20 hari dan dipindahkan ke pot penanaman. Selama fase perkecambahan, diberi nutrisi setiap tiga hari sekali.

Penelitian ini menggunakan komposisi larutan nutrisi berdasarkan penelitian Yoshida et al. (1972), yaitu: $\mathrm{NH}_{4} \mathrm{NO}_{3} 91.4$ g/l, $\mathrm{K}_{2} \mathrm{SO}_{4} 71.4 \mathrm{~g} / \mathrm{l}, \mathrm{KH}_{2} \mathrm{PO}_{4} 23.1 \mathrm{~g} / \mathrm{l}, \mathrm{K}_{2} \mathrm{HPO}_{4}$ $4.3 \mathrm{~g} / \mathrm{l}, \mathrm{CaCl}_{2} 443 \mathrm{~g} / \mathrm{l}, \mathrm{MgSO}_{4} .7 \mathrm{H}_{2} \mathrm{O} 324 \mathrm{~g} / \mathrm{l}, \mathrm{MnCl}_{2} .4 \mathrm{H}_{2} \mathrm{O} 1.5 \mathrm{~g} / \mathrm{l},\left(\mathrm{NH}_{4}\right)_{6} . \mathrm{Mo}_{2} \mathrm{O}_{2} 4.4 \mathrm{H}_{2} \mathrm{O}$ $0.074 \mathrm{~g} / \mathrm{l}, \mathrm{H}_{3} \mathrm{BO}_{3} 0.93 \mathrm{~g} / \mathrm{l}, \mathrm{ZnSO}_{4} .7 \mathrm{H}_{2} \mathrm{O} 0.035 \mathrm{~g} / \mathrm{l}, \mathrm{CuSO}_{4} .5 \mathrm{H}_{2} \mathrm{O} 0.03 \mathrm{~g} / \mathrm{l}$, FeNaEDTA 10.5 g/l, dan $\mathrm{FeSO}_{4} 2.5$ g/l. Setiap bahan kimia yang telah dilarutkan, diambil sebanyak 12.5 ml untuk dicampur dengan 10 liter aquadest, kecuali $\mathrm{NH}_{4} \mathrm{NO}_{3}$. Konsentrasi $\mathrm{NH}_{4} \mathrm{NO}_{3}$ dibedakan menjadi dua, yaitu sub optimal $(0.36 \mathrm{mM})$ dan optimal $(25 \mathrm{mM})$. Setelah larutan dibuat, pengukuran $\mathrm{pH}$ mencapai 6.5.

Penanaman padi dilakukan secara hidroponik yaitu bibit padi ditanam pada pot yang telah berisi media pasir dan diberi larutan nutrisi secara rutin dan kondisi pertanaman harus tergenang. Larutan nutrisi yang diberikan juga berbeda kandungan unsur nitrogennya, yaitu sesuai dengan perlakuan yang diberikan (sub optimal dan optimal). Kegiatan penanaman padi dibedakan menjadi dua jenis bahan tanam dan 
diletakkan pada lajur yang berbeda, yaitu tanaman mutasi optimal dimulai nomor 1-50, sedangkan yang tidak dimutasi nomor 51-60. Tanaman mutasi sub optimal dimulai nomor 61-110, sedangkan yang tidak dimutasi mulai nomor 111-120.

Perawatan yang dilakukan adalah pencabutan gulma serta pemberian larutan nutrisi secara rutin pada tanaman sampai kondisi pertanaman tergenang.

(1)Pengukuran tinggi tanaman, dilakukan setiap 10 hari sekali, yaitu pada saat tanaman berumur 45, 55, dan 65 HST. (2) Perhitungan jumlah anakan, dihitung dengan cara menghitung jumlah anakan yang tumbuh dari batang utama dan dilakukan bersamaan dengan pengukuran tinggi tanaman. (3) Pengukuran kandungan klorofil, diukur dengan menggunakan chollophyl meter SPAD 502 pada saat tanaman berumur 45, 55, dan 65 HST. (4) Pengambilan sampel dan penentuan konsentrasi nitrat dan ammonium, pengambilan sampel larutan nutrisi dilakukan pada saat tanaman berumur 45, 55, dan 65 HST. Larutan nutrisi diambil dari media tumbuh sebanyak $5 \mathrm{ml}$ untuk diketahui konsentrasi unsur nitrogennya (amonium dan nitrat) dan diambil dari 2 titik pada masingmasing tanaman padi yang ditumbuhkan. Konsentrasi nitrat dianalisis dengan menggunakan metode spektrofotometer berdasarkan prosedur Cataldo et al. (1976), sedangkan konsentrasi amonium dianalisis dengan metode cawan-conway.

Analisis data dilakukan dengan cara deskriptif, yaitu dengan melakukan interpretasi terhadap data - data yang telah diperoleh melalui pengamatan dan perhitungan yaitu mengenai hasil padi mutan maupun kontrol yang memiliki tingkat serapan unsur hara $\mathrm{N}$ yang paling tinggi, baik pada kondisi $\mathrm{N}$ sub optimal maupun kondisi $\mathrm{N}$ optimal.

\section{Tinggi Tanaman}

\section{HASIL DAN PEMBAHASAN}

Engelstad (1997) menyatakan bahwa pemberian nitrogen yang optimal pada tanaman mampu meningkatkan pertumbuhan serta meningkatkan sintesis protein. Pertumbuhan tinggi tanaman padi yang diberi larutan nutrisi dengan kandungan $\mathrm{N}$ optimal lebih cepat dibandingkan dengan kandungan $\mathrm{N}$ sub optimal, yaitu dapat dilihat pada Gambar 1. dan Gambar 2.
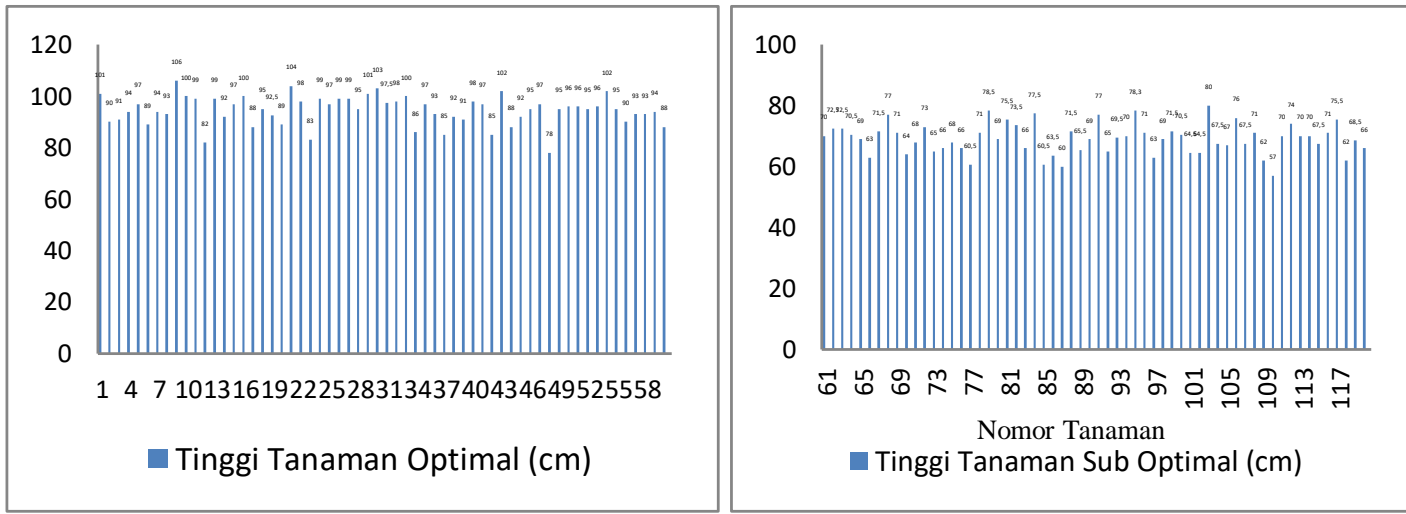
Gambar 1. Tinggi Tanaman Padi pada Kondisi N Optimal
Gambar 2. Tinggi Tanaman Padi pada Kondisi N sub Optimal

Gambar 1. menunjukkan tinggi tanaman padi berkisar antara $78 \mathrm{~cm}$ sampai 106 cm ketika berada pada kondisi N optimal, sedangkan pada Gambar 2. hanya berkisar antara $57 \mathrm{~cm}$ sampai dengan $80 \mathrm{~cm}$. Hal ini sesuai dengan hasil penelitian Kaya (2013) yaitu peningkatan tinggi tanaman padi diiringi dengan meningkatnya ketersediaan nitrogen dalam tanah dan serapan nitrogen oleh tanaman. Menurut Mapegau (2007), meningkatnya tinggi tanaman yang diberi unsur $\mathrm{N}$ dapat terjadi karena nitrogen tersebut dapat meningkatkan efektivitas nitrogenase, sehingga jumlah nitrogen yang difiksasi akan menjadi lebih tinggi. Hal ini berdampak pada peningkatan unsur hara nitrogen dalam tanah sehingga dapat meningkatkan pertumbuhan tanaman.

Tanaman yang dimutasi mengalami peningkatan tinggi tanaman yang lebih cepat dibandingkan yang tidak dimutasi, meskipun selisih antara keduanya tidak terpaut jauh. Peningkatan tinggi tanaman yang mengalami perlakuan menunjukkan adanya perubahan fenotipik pada tinggi tanaman tersebut. Tanaman yang tidak terlalu tinggi merupakan sasaran dari kebanyakan pemulia tanaman padi. Pheng et al., (2008) menyatakan bahwa tinggi tanaman padi yang ideal adalah $90-100 \mathrm{~cm}$, sehingga dengan tinggi tersebut potensi kerebahan tanaman padi akan menurun dibandingkan dengan tanaman padi yang terlalu tinggi.

\section{Jumlah Anakan}

Pembentukan anakan mulai berlangsung sejak munculnya anakan pertama sampai pembentukan anakan maksimum tercapai. Ketika anakan maksimal telah tercapai, maka sebagian dari anakan tersebut akan mati dan tidak menghasilkan malai. Menurut Meliala dkk. (2016), kemampuan tanaman padi dalam membentuk anakan dipengaruhi oleh ketersediaan hara dan kemampuan tanaman dalam menghasilkan anakan atau faktor genetis dari tanaman tersebut.

Berdasarkan hasil penelitian yang tertera pada Gambar 3. dan Gambar 4. dapat diketahui bahwa jumlah anakan padi per rumpun meningkat ketika berada pada kondisi $\mathrm{N}$ optimal dibandingkan kondisi $\mathrm{N}$ sub optimal. Jumlah anakan padi ketika berada pada kondisi $\mathrm{N}$ optimal bisa mencapai anakan tertinggi sebanyak 25 anakan dan terendahnya 8 anakan, yaitu pada tanaman hasil mutasi nomor 23. Sedangkan ketika berada pada 
kondisi $\mathrm{N}$ sub optimal, jumlah anakan tertingginya hanya mencapai 6 anakan bahkan terendahnya bisa mencapai 3 anakan. Selisih antara keduanya sangat jauh dan hal ini sesuai dengan hasil penelitian Jamilah dan Safridar, (2012) yaitu pemberian unsur N yang cukup dapat menyumbangkan unsur hara yang dibutuhkan oleh tanaman yang dapat memberikan pengaruh terhadap pertumbuhan anakan tanaman padi supaya lebih optimal.

Penanaman M1 padi ciherang dengan EMS dan kandungan $\mathrm{N}$ tertentu dalam larutan nutrisi yang diberikan menghasilkan keragaman yang tinggi, baik secara kualitatif maupun kuantitatif. Perubahan yang terjadi pada tanaman dapat disebabkan sebagai akibat dari perlakuan, namun dapat juga disebabkan oleh faktor luar atau lingkungan tanam. Jumlah anakan padi yang telah dimutasi menghasilkan anakan yang relatif lebih rendah pertumbuhannya dibandingkan dengan yang tidak dimutasi serta hasil pertumbuhannya juga beragam. Keanekaragaman genetik yang dihasilkan akibat proses mutasi dapat ditunjukkan secara fenotip maupun tidak terekspresi.

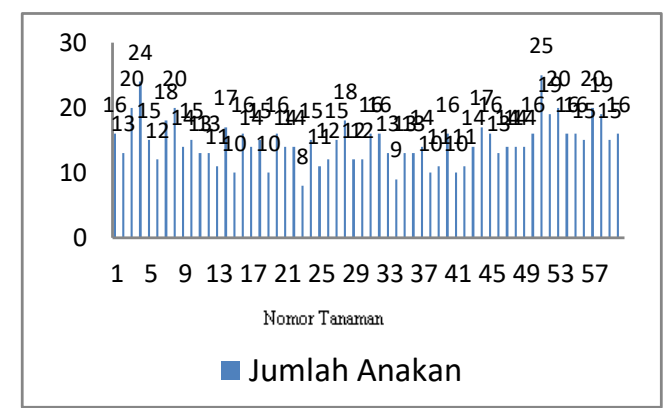

Gambar 3. Jumlah anakan Padi pada Kondisi N Optimal

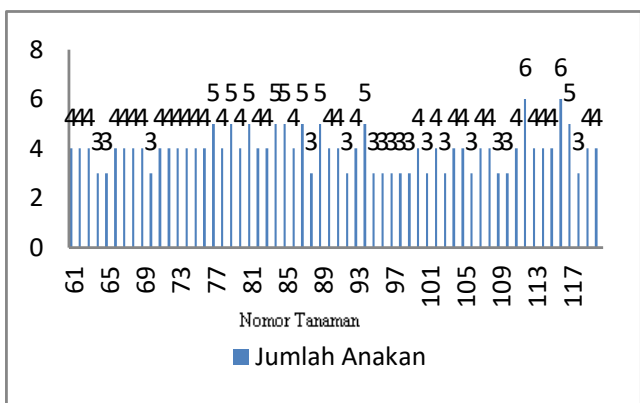

Gambar 4. Jumlah anakan Padi pada Kondisi $\mathrm{N}$ sub Optimal

Berdasarkan Gambar 3. dan Gambar 4. setiap tanaman padi, baik yang dimutasi maupun tidak memiliki jumlah anakan yang beragam. Jumlah anakan tertinggi pada tanaman hasil mutasi yaitu 20 anakan, sebaliknya pada tanaman yang tidak dimutasi dapat mencapai 25 anakan. Jumlah anakan terendah pada tanaman padi hasil mutasi dan tidak dimutasi sama, yaitu 3 anakan. Adanya variasi tersebut menunjukkan bahwa mutasi dengan menggunakan mutagen kimia, yaitu EMS dapat memberikan pengaruh yang berbeda pada setiap tanaman yang telah dimutasi.

\section{Kandungan Klorofil}

Sumenda dkk, (2011) menyatakan bahwa pertumbuhan dan perkembangan tanaman dipengaruhi oleh faktor eksternal dan internal. Faktor eksternal meliputi tanah, kelembaban, air, dan cahaya. Faktor internal dapat mencakup gen, hormon, struktur anatomi dan morfologi organ tumbuhan, serta kandungan klorofil. Klorofil berperan sebagai penyerap energi radiasi matahari yang diperlukan tanaman dalam melakukan 
proses fotosintesis dan menghasilkan sejumlah asimilat. Asimilat inilah yang akhirnya akan berperan sebagai energi pertumbuhan (Setyani et al., 2013). Apabila kandungan N di dalam tanah terlalu rendah, maka kemampuan tanaman untuk menghasilkan asimilat juga akan rendah, yang akhirnya akan berdampak pada rendahnya laju pertumbuhan tanaman.

Klorofil termasuk salah satu faktor untuk menentukan status $\mathrm{N}$ daun (Peterson et al., 1996). Kandungan klorofil diukur dengan menggunakan alat SPAD. Pengukuran dengan SPAD sangat memudahkan untuk mengukur tingkat kehijauan daun, yang menunjukkan jumlah klorofil yang dimiliki oleh tanaman. Pertumbuhan tanaman akan semakin baik apabila daun memiliki kandungan klorofil yang semakin tinggi (Lintang, 2012). Warna daun padi pada kondisi $\mathrm{N}$ optimal terlihat jauh lebih hijau dan gelap dibandingkan dengan daun padi yang berada pada kondisi $\mathrm{N}$ sub optimal, yaitu berwarna hijau kekuningan atau warnanya hijau muda. Hal tersebut menunjukkan bahwa kebutuhan hara $\mathrm{N}$ tanaman padi dengan kondisi $\mathrm{N}$ optimal sudah tercukupi, sedangkan pada kondisi $\mathrm{N}$ sub optimal kebutuhan hara $\mathrm{N}$ nya masih kurang.

Berdasarkan Gambar 5. dan Gambar 6. dapat diketahui bahwa kandungan klorofil ketika berada pada kondisi $\mathrm{N}$ optimal akan lebih banyak dibandingkan pada kondisi $\mathrm{N}$ sub optimal. Kandungan klorofil tertinggi pada tanaman dengan kondisi $\mathrm{N}$ optimal bisa mencapai 40.8 unit, sedangkan pada kondisi $\mathrm{N}$ sub optimal hanya mencapai 31.6 unit. Sebaliknya kandungan klorofil terendah pada tanaman padi dengan kondisi $\mathrm{N}$ optimal yaitu 34.9 unit dan pada kondisi N sub optimal bisa mencapai 22.8 unit. Disisi lain, kandungan klorofil pada tanaman padi hasil mutasi sedikit lebih rendah dibandingkan dengan yang tidak dimutasi, meskipun selisihnya hanya sedikit. Tanaman hasil mutasi dengan kondisi $\mathrm{N}$ optimal, nilai kandungan klorofil tertinggi yaitu 39.5 unit, sedangkan yang tidak dimutasi 40.8 unit. Sebaliknya, pada tanaman padi hasil mutasi dengan kondisi $\mathrm{N}$ sub optimal, nilai tertingginya adalah 31.6 unit dan pada tanaman padi yang tidak dimutasi adalah 31.4 unit.

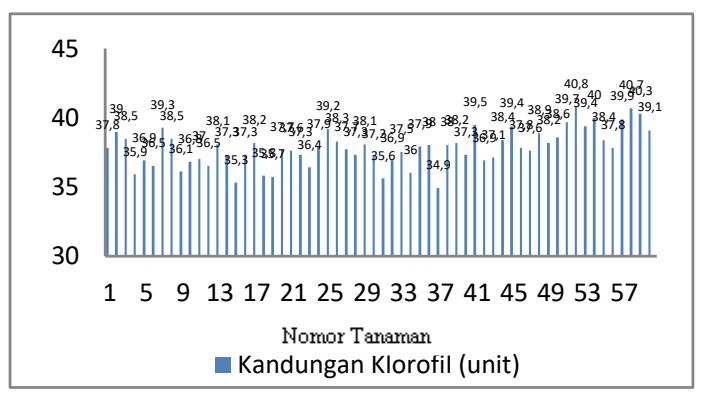

Gambar 5. Kandungan Klorofil Padi pada Kondisi N Optimal

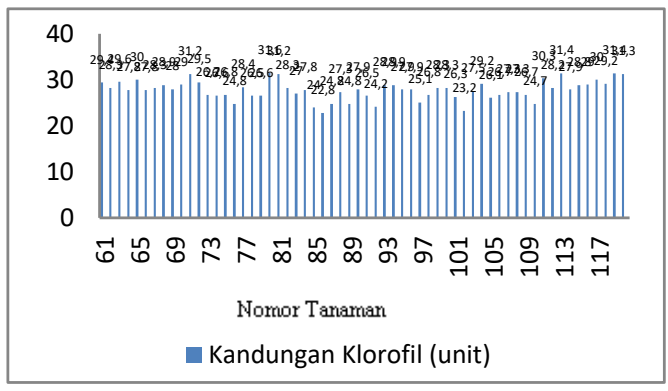

Gambar 6. Kandungan Klorofil Padi pada Kondisi N sub Optimal 
Mutasi yang terjadi pada bagian klorofil menunjukkan kemungkinan terjadinya mutasi di dalam genom inti. Sugimoto dkk, (2004) menyatakan bahwa genom inti akan mengkode protein kloroplas. Diferensiasi kloroplas terjadi akibat impor protein yang dikodekan oleh genom inti serta sitoplasma yang terlibat dalam penargetan protein, sehingga kloroplas tersebut membutuhkan koordinasi ekspresi dari gen-gen inti.

Mekanisme klorofil dalam upaya meningkatkan kualitas dan produksi tanaman dimulai ketika klorofil tersebut aktif dalam proses fotosintesis. Energi yang telah dihasilkan dari proses fotosintesis akan digunakan tanaman untuk melakukan prosesproses pembentukan unsur nutrisi tanaman, seperti penyerapan $\mathrm{N}$ dalam penyusunan protein untuk meningkatkan kualitasnya serta digunakan tanaman dalam melakukan proses-proses pertumbuhan (Li et al., 2006).

\section{Serapan Nitrat}

Nitrogen termasuk komponen penting dari berbagai macam biomolekul, termasuk DNA, protein, dan klorofil. Umumnya unsur nitrogen diserap oleh tanaman dalam bentuk $\mathrm{NH}_{4}{ }^{+}$atau $\mathrm{NO}_{3}$. Unsur nitrogen yang masuk ke dalam sel tanaman akan di metabolisme dan dikatalisis oleh beberapa enzim, seperti Nitrate Reduktase (NR), Glutamine Synthetase (GS), dan Glutamate Dehydigenase (GDH).

Nitrat merupakan ion yang keberadaannya di dalam tanah sangat mobil, karena sifatnya yang mudah sekali larut dan tidak terjerap oleh koloid tanah. Menurut Mukhlis dan Fauzi (2003), ion nitrat bergerak di dalam tanah mengikuti proses difusi serta aliran massa. Besarnya difusi nitrat dipengaruhi oleh besarnya koefisien nitrifikasi serta banyaknya jumlah senyawa amonium yang terdapat dalam larutan tanah (Tillman and Scotter, 1991). Sedangkan besarnya pergerakan $\mathrm{NO}_{3}{ }^{-}$secara aliran massa dipengaruhi oleh beberapa faktor, yaitu antara lain kadar dan potensial air tanah, transpirasi, porositas tanah, dan faktor-faktor yang menentukan besarnya koefisien nitrifikasi dan jumlah senyawa yang ada dalam larutan tanah.

Berdasarkan Gambar 7. dan Gambar 8. dapat diketahui bahwa serapan nitrat pada kondisi $\mathrm{N}$ optimal lebih baik dibandingkan dengan kondisi $\mathrm{N}$ sub optimal. Hal ini dapat dilihat dari nilai tertinggi serapan nitrat pada tanaman padi dengan kondisi $\mathrm{N}$ optimal, yaitu sebesar $0.012503 \mu \mathrm{g} / \mathrm{ml} / 3$ jam pada tanaman non mutasi nomor 51 , sedangkan pada kondisi $\mathrm{N}$ sub optimal nilai tertinggi sebesar $0.00048666 \mu \mathrm{g} / \mathrm{ml} / 3$ jam pada tanaman non mutasi nomor 116. Adapun nilai serapan nitrat terendah pada kondisi $\mathrm{N}$ optimal sebesar $0.020903 \mu \mathrm{g} / \mathrm{ml} / 3 \mathrm{jam}$, yaitu pada tanaman mutasi nomor 25 dan pada kondisi $\mathrm{N}$ sub 
optimal sebesar $-0.0004233 \mu \mathrm{g} / \mathrm{ml} / 3$ jam, yaitu pada tanaman mutasi nomor 91 . Serapan nitrat tersebut dihitung dari selisih antara jumlah nitrat pada pengamatan pertama dikurangi dengan jumlah nitrat pada pengamatan kedua dengan selisih waktu 3 jam.

Serapan nitrat pada kondisi N optimal banyak menunjukkan nilai yang negatif. Nilai negatif tersebut dapat terjadi karena jumlah nitrat pada pengamatan kedua lebih tinggi dibandingkan dengan awal pengamatan atau bisa dikatakan adanya peningkatan kandungan nitrat setelah 3 jam dari pengamatan pertama. Padahal seharusnya ketika dibiarkan selama 3 jam untuk menghomogenkan kandungan $\mathrm{N}$, kandungan nitrat berkurang dalam media tanam. Adanya kandungan nitrat yang meningkat pada pengamatan kedua dapat disebabkan oleh kondisi lingkungan pada media tanam secara hidroponik tersebut banyak ditemukan tanaman Azolla pinnata maupun lumut kerak, seperti yang dapat dilihat pada Gambar 9. dan Gambar 10. Kandungan nitrat yang meningkat juga dapat disebabkan oleh cepatnya laju proses nitrifikasi.

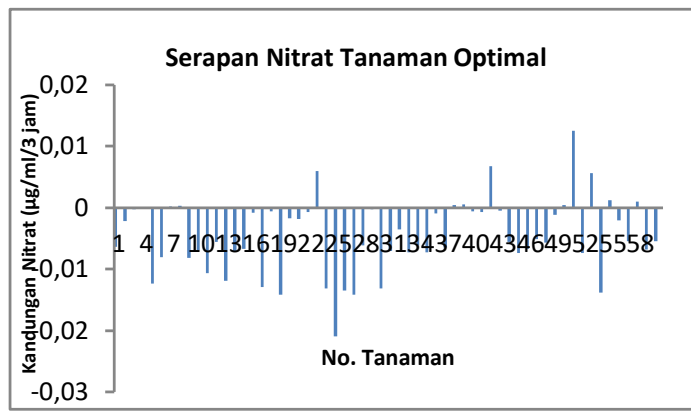

Gambar 7. Serapan Nitrat Padi pada Kondisi N Optimal

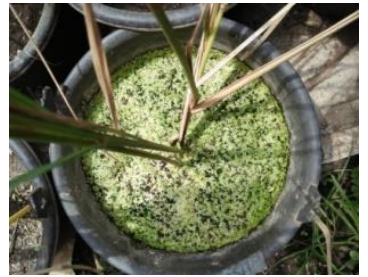

Gambar 9. Azolla pinnata

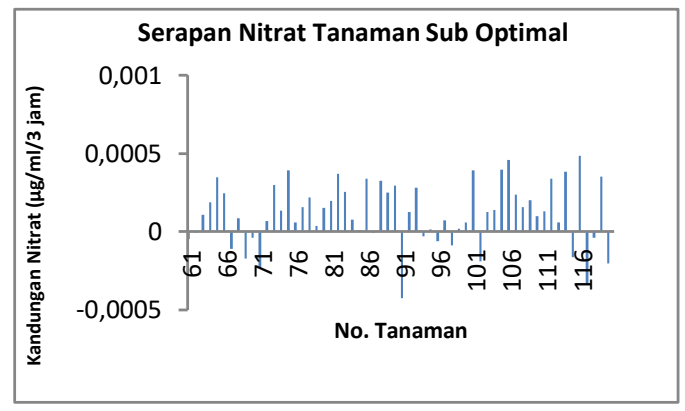

Gambar 8. Serapan Nitrat Padi pada Kondisi $\mathrm{N}$ sub Optimal

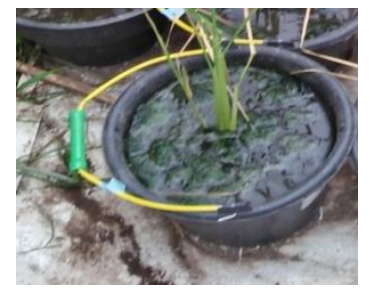

Gambar 10. Lumut Kerak

Azolla pinnata merupakan tanaman yang memiliki kemampuan untuk bersimbiosis dengan mikroorganisme pengikat nitrogen yaitu Anabaena azollae, sehingga secara tidak langsung tanaman tersebut memiliki kemampuan untuk mereduksi nitrogen bebas $\left(\mathrm{N}_{2}\right)$ dari atmosfer menjadi amonia melalui enzim denitrogenase yang dapat diserap tanaman padi saat diinkorporasikan ke dalam tanah (Amir dkk, 2012). Jumlah unsur nitrogen yang dapat ditambat dari hasil simbiosis antara Azolla pinnata dengan Anabaena azollae tersebut cukup tinggi. 
Azolla pinnata memiliki kandungan bahan organik yang cukup tinggi, sehingga dapat meningkatkan aktivitas mikroba yang berada dalam tanah (Mulyanto dkk, 2018). Nitrogen yang dihasilkan oleh Azolla baru akan tersedia untuk tanaman padi ketika telah mengalami proses mineralisasi dalam tanah (Putra dkk, 2013). Perubahan bentuk nitrogen dalam tanah yang berasal dari bahan organik dapat terjadi melalui proses nitrifikasi, yaitu perubahan bentuk nitrogen dari amonium menjadi nitrit oleh bakteri Nitrosomonas, kemudian diubah menjadi nitrat oleh Nitrobacter. Azolla juga dapat berfungsi sebagai penekan hilangnya $\mathrm{N}$ karena penguapan atau volatisasi yang berada pada media tanam padi selama siklus hidup padi sawah (Krock et al., 1988).

Faktor lain yang bisa menyebabkan meningkatnya kandungan $\mathrm{N}$ adalah adanya lumut kerak yang berada di media tanam padi. Lumut kerak (Lichenes) merupakan suatu organisme majemuk dan termasuk bentuk simbiosis mutualisme erat dari fungus (sebagai mycobiont) dengan mitra fotosintetik (photobiont), yang dapat berupa alga hijau (biasanya Trebouxia) atau Cyanobacteria (biasanya Nostoc). Nostoc tumbuh subur dan memfiksasi $\mathrm{N}_{2}$ dari udara sehingga dapat membantu penyediaan nitrogen yang dibutuhkan oleh padi.

Menurut Subramani (1980) dampak positif dari Cyanobacteria adalah mampu menyediakan $25 \mathrm{~kg} \mathrm{~N} \mathrm{ha}^{-1}$. Cyanobacteria menambat nitrogen bebas dalam bentuk dinitrogen $\left(\mathrm{N}_{2}\right)$ di atmosfer (Gardner et al., 1991). Penambatan $\mathrm{N}_{2}$ oleh Cyanobacteria berlangsung melalui bantuan enzim nitrogenase. Katalisis nitrogen pada kompleks enzim nitrogenase melibatkan feredoksin (Graham and Wilcox, 2000). Feredoksin termasuk protein pereduksi yang berperan dalam mereduksi protein Fe pada kompleks enzim nitrogenase. Aktivitas dari penambatan nitrogen dimulai dari reduksi feredoksin kemudian dihasilkan elektron. Elektron hasil reduksi feredoksin tersebut akan ditransfer ke protein Fe pada kompleks enzim nitrogenase. Setelah menerima elektron, protein Fe akan tereduksi. Elektron hasil reduksi protein Fe kemudian akan ditransfer ke protein Mo-Fe. Setelah menerima elektron, protein Mo-Fe akan tereduksi. Elektron dari protein Mo-Fe selanjutnya ditransfer ke $\mathrm{N}_{2}$, yang masuk ke dalam sel heterokis secara difusi. $\mathrm{N}_{2}$ kemudian direduksi menjadi $\mathrm{NH}_{3} \cdot \mathrm{NH}_{3}$ selanjutnya akan diubah menjadi glutamin di sel heterokis lalu ditransportasikan ke sel-sel vegetatif Nostoc (Adhikary and Pattanaik, 2006). Reaksi kimia dan skema penambatan nitrogen dapat dilihat pada Gambar 11. sebagai berikut: 


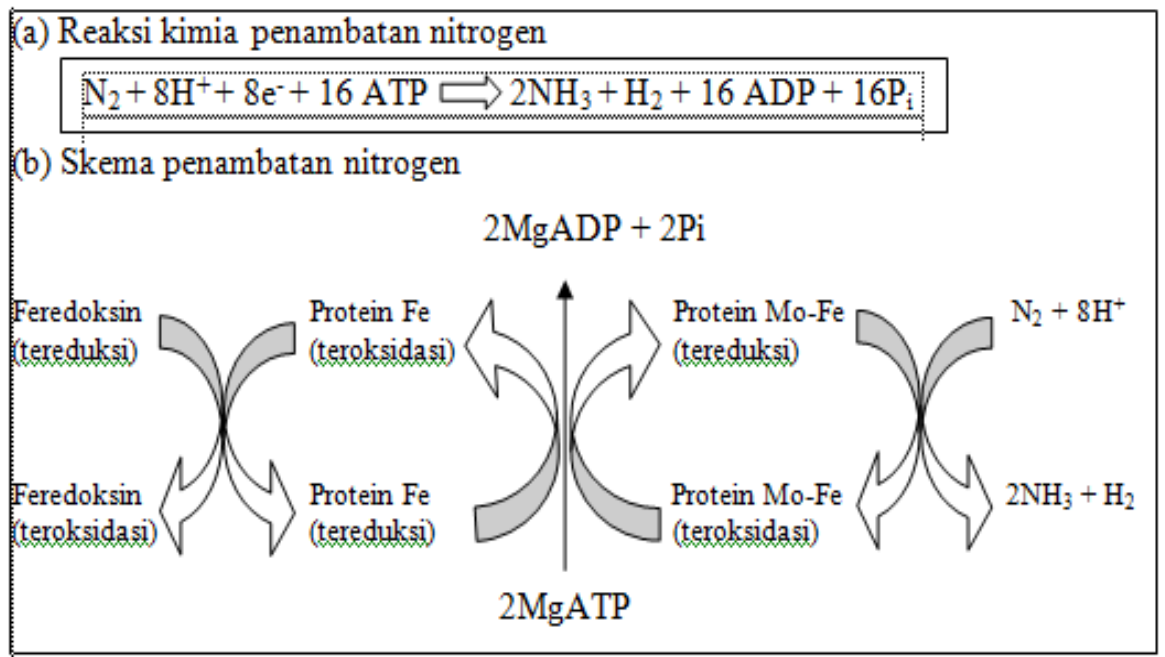

Gambar 11. Reaksi Kimia dan Skema Penambatan Nitrogen

[Sumber: a. Modifikasi Vaishampayan et al., 2001; b. Taiz and Zeiger 2002]

Kandungan nitrat yang meningkat pada pengamatan kedua juga bisa disebabkan oleh cepatnya laju proses nitrifikasi. Nitrifikasi merupakan proses yang dilakukan oleh mikroorganisme dalaam mengubah ammonium menjadi nitrat untuk menghasilkan energi (Hardjowigeno, 2010). Menurut Adiwiganda and Wild (1989), terbentuknya nitrat tidak terlepas dari adanya proses nitrifikasi yang sangat dipengaruhi oleh kondisi kelembaban tanah. Apabila kadar air dalam tanah berkurang, maka akan berpeluang terjadinya proses oksidasi terhadap amonium sehingga terbentuk senyawa nitrit dan nitrat. Proses nitrifikasi tersebut akan terjadi lebih cepat apabila berada pada kondisi tanah hangat $\left(20-35^{\circ} \mathrm{C}\right)$, lembab, serta beraerasi baik. Selain itu, $\mathrm{pH}$ tanah yang mendekati netral juga akan memberi peluang bagi percepatan proses nitrifikasi.

Konversi amonium menjadi nitrat dilakukan oleh bakteri yang hidup di dalam tanah dan bakteri nitrifikasi lainnya. Tahap utama nitrifikasi yaitu, bakteri nitrifikasi seperti spesies Nitrosomonas akan mengoksidasi $\mathrm{NH}_{4}{ }^{+}$dan mengubah amonia menjadi $\mathrm{NO}_{2}$. Sedangkan spesies bakteri lain, seperti Nitrobacter akan bertanggung jawab untuk oksidasi nitrit menjadi $\mathrm{NO}_{3}{ }^{-}$.

Kandungan nitrat yang berkurang pada pengamatan kedua dapat disebabkan oleh pencucian atau terlindi (leaching) $\mathrm{NO}_{3}{ }^{-}$, denitrifikasi $\mathrm{NO}_{3}{ }^{-}$menjadi $\mathrm{N}_{2}$, immobilisasi, serta dikonsumsi oleh tanaman padi itu sendiri. Pencucian atau leaching $\mathrm{NO}_{3}^{-}$merupakan proses tercucinya unsur nitrat dalam konsentrasi yang tinggi. Partikel pasir atau tanah tidak mampu menahan nitrat karena muatan atom negatifnya, sehingga nitrat sangat mudah terbawa air dalam tanah. Hal ini didukung oleh pernyataan Handayanto dan Hairiah (2009), yaitu nitrat dalam tanah akan mudah tercuci karena bermuatan negatif. Berkebalikan dengan ammonium yang bermuatan positif, sehingga keberadaanya dapat 
terikat oleh koloid tanah. Hardjowigeno (2010) menyatakan bahwa arah pencucian hara tanah selalu menuju pada lapisan bawah daerah perakaran tanaman, sehingga sulit untuk dimanfaatkan oleh tanaman. Oleh sebab itu tidak mengherankan apabila keberadaan nitrat di permukaan tanah hampir sangat sedikit ditemukan.

Rendahnya kadar nitrat juga dapat disebabkan karena kondisi tanah yang tergenang, sehingga menghambat proses nitrifikasi dan yang terjadi adalah proses denitrifikasi (D'Haene et al., 2003). Denitrifikasi merupakan proses hilangnya unsur nitrogen melalui konversi nitrat menjadi bentuk gas nitrogen yang menguap di udara, contohnya menjadi bentuk oksida seperti Nitric Oxide, Nitrous Oxide, dan Dinitrous Oxide. Proses denitrifikasi terjadi karena suasana anaerob dan adanya bakteri denitrifikan, yaitu ketika kondisi tanah jenuh dan bakteri kemudian menggunakan nitrat sebagai salah satu sumber oksigen. Bakteri anaerob, misalnya Pseudomonas, Bacillus menggunakan $\mathrm{N}$ sebagai sumber $\mathrm{O}_{2}$ dalam respirasi dan terjadi pada tanah tergenang, sekitar akar atau seresah yang sedang terombak. Hal ini dapat merugikan karena mengurangi ketersediaan $\mathrm{N}$ dalam tanah.

Kandungan nitrogen di dalam tanah juga dapat berkurang karena proses immobilisasi, dimana immobilisasi merupakan kebalikan dari proses mineralisasi. Immobilisasi berkaitan dengan proses dikonsumsinya unsur nitrat dan ammonium oleh organisme tanah, sehingga keduanya menjadi tidak dapat dikonsumsi oleh tanaman. Immobilisasi $\mathrm{N}$ oleh mikroorganisme dapat berpengaruh pada jumlah $\mathrm{N}$ yang tersedia bagi tanaman, karena terdapat kompetisi antara tanaman dengan mikroorganisme dalam memperoleh N. Immobilisasi ini hanya mengunci sementara unsur $\mathrm{N}$ dan ketika mikroorganisme mati, unsur $\mathrm{N}$ organik yang terdapat dalam sel akan diubah kembali melalui proses mineralisasi dan nitrifikasi sehingga menghasilkan unsur nitrat yang dapat dikonsumsi tanaman.

Kehilangan nitrat juga dapat terjadi karena diserap oleh tanaman itu sendiri (crop uptake). Crop uptake merupakan tujuan utama dari manajemen nitrogen dilahan pertanian. Efisiensi $\mathrm{N}$ tergantung pada beberapa faktor termasuk suhu, kelembaban tanah, tekanan hama, serta pemadatan tanah. Penggunaan secara efisien unsur N selama musim tanam dan penggunaan tanaman penutup (cover crop) dapat meminimalkan kehilangan unsur nitrogen yang berada dalam tanah. Faktor yang dapat mempengaruhi penyerapan serta akumulasi nitrat yaitu faktor genetik, faktor lingkungan (kelembaban atmosfer, radiasi, penyinaran, kadar air substrat), dan faktor pertanian (dosis nitrogen dan bentuk kimia, ketersediaan nutriens lainnya, penggunaan herbisida (Santamaria, 2006). 
Tanaman dilahan kering umumnya menyerap $\mathrm{NO}_{3}{ }^{-}$relatif lebih besar apabila dibandingkan dengan $\mathrm{NH}_{4}{ }^{+}$. Pada $\mathrm{pH}$ rendah, nitrat akan diserap lebih cepat dibandingkan dengan ammonium. Hal ini sesuai dengan Afandie (2002) yang menyatakan bahwa pada $\mathrm{pH}$ 4,0 penyerapan nitrat akan lebih banyak dibandingkan dengan penyerapan ammonium. Sedangkan pada $\mathrm{pH}$ netral, kemungkinan ada penyerapan keduanya seimbang. Hal ini bisa disebabkan oleh adanya persaingan anion $\mathrm{OH}$ dengan anion $\mathrm{NO}_{3}{ }^{-}$, sehingga penyerapan nitrat menjadi sedikit terhambat. Menurut Novizan (2005), ion nitrat maupun ion ammonium, keduanya diserap oleh tanaman melalui mekanisme pertukaran kation. Mekanisme ini terjadi akibat pernapasan akar menghasilkan $\mathrm{CO}_{2}$ yang bergabung dengan air didalam tanah kemudian membentuk $\mathrm{H}_{2} \mathrm{CO}_{3}$. Selanjutnya $\mathrm{H}_{2} \mathrm{CO}_{3}$ tersebut terurai membentuk $\mathrm{H}^{+}$dan $\mathrm{HCO}_{3}$. Ion $\mathrm{H}^{+}$yang berada pada permukaan atau di dalam akar akan bertukar posisi dengan unsur hara yang terikat pada koloid tanah. Pada bagian akar ini akan terjadi kegiatan respirasi dalam jumlah besar.

\section{Serapan Ammonium}

Senyawa ammonium adalah salah satu bentuk nitrogen lain yang dapat diserap oleh tanaman. Tanaman yang hidupnya pada media yang banyak terdapat air, maka akan lebih suka menyerap $\mathrm{N}$ dalam bentuk $\mathrm{NH}_{4}{ }^{+}$. Nitrogen dalam bentuk ammonium lebih efektif dibandingkan bentuk nitrat dalam upaya peningkatan produksi tanaman padi (Leiwakabessy dan Sutandi, 1998). Kecepatan terbentuknya $\mathrm{NH}_{4}{ }^{+}$termasuk indeks yang baik untuk kemampuan tanah dalam memenuhi kebutuhan $\mathrm{N}$ tanaman padi. Diantara bentuk nitrogen lainnya didalam tanah, $\mathrm{NH}_{4}{ }^{+}$termasuk bentuk nitrogen yang paling mudah digunakan oleh tumbuhan karena efesiensinya dalam metabolisme sel tumbuhan. Menurut Salisbury and Ross (1995), $\mathrm{NH}_{4}{ }^{+}$merupakan ion yang memiliki muatan positif dan dapat terserap oleh koloid tanah, sehingga mudah untuk dimanfaatkan oleh tumbuhan. $\mathrm{NH}_{4}{ }^{+}$yang bermuatan positif juga menyebabkannya tidak mudah untuk tercuci bersama dengan air.

Pola pergerakan $\mathrm{NH}_{4}{ }^{+}$hampir sama dengan nitrat. Mukhlis dan Fauzi (2003) menyatakan bahwa pergerakan $\mathrm{NH}_{4}{ }^{+}$dalam tanah dipengaruhi oleh aliran massa, difusi, air tanah, hidrolisis urea, mineral liat, $\mathrm{pH}$, serta aktivitas bakteri nitrifikasi. $\mathrm{NH}_{4}{ }^{+}$di dalam tanah juga mudah mobil melalui proses difusi maupun aliran massa. Jika dibandingkan dengan $\mathrm{NO}_{3}{ }^{-}$, pergerakan $\mathrm{NH}_{4}{ }^{+}$jauh lebih lambat. Keadaan ini disebabkan oleh beberapa faktor, antara lain yaitu a. Ion $\mathrm{NH}_{4}{ }^{+}$merupakan kation yang dapat teradsorbsi di permukaan koloid tanah, sehingga gerakan difusinya lebih kecil apabila dibandingkan dengan $\mathrm{NO}_{3}{ }^{-}$yang senantiasa bebas di larutan tanah (Wild, 1981). b. Ion $\mathrm{NH}_{4}{ }^{+}$di tanah sawah yang jenuh air lebih kecil aliran massa yang terjadi, karena aliran berbanding 
terbalik dengan kadar air tanah (Hillel, 1980). c. Ion $\mathrm{NH}_{4}{ }^{+}$terkadang terfiksasi di antara dua lempeng mineral liat, sehingga tidak mungkin berpindah baik secara difusi maupun aliran massa (Mengel and Kirkby, 1982).

Serapan nitrogen oleh tanaman berhubungan positif dan cukup erat kaitannya dengan kadar nitrogen tanah yang diberikan. Berdasarkan Gambar 12. dan Gambar 13. dapat diketahui bahwa serapan ammonium pada kondisi $\mathrm{N}$ optimal lebih baik dibandingkan pada kondisi N sub optimal. Serapan ammonium tertinggi pada kondisi N optimal bisa mencapai $10.3 \mu \mathrm{g} / \mathrm{ml} / 3$ jam yaitu pada tanaman hasil mutasi nomor 37 , sedangkan pada kondisi $\mathrm{N}$ sub optimal nilai serapan tertingginya hanya mencapai 1.23
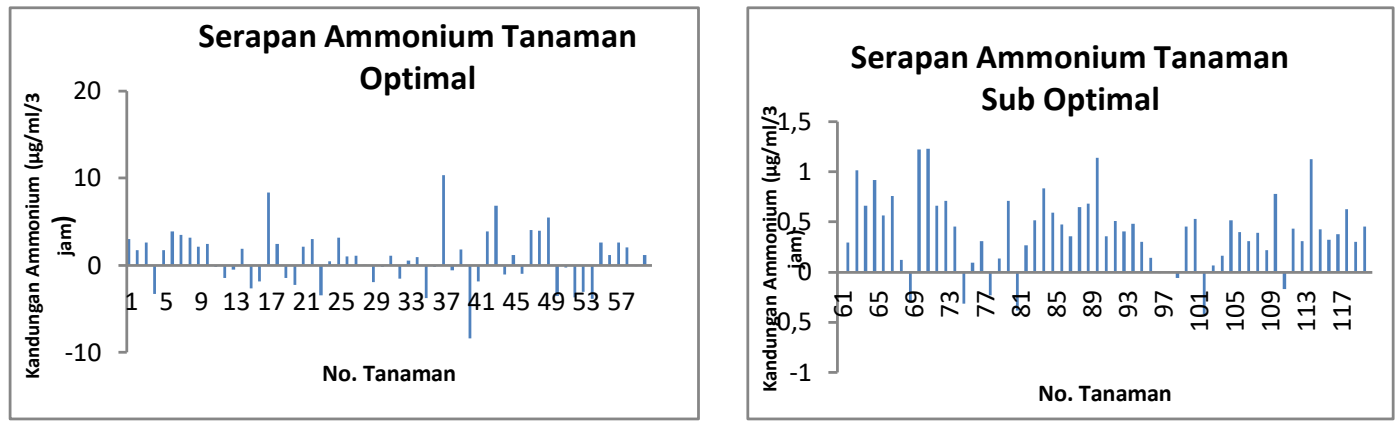

$\mu \mathrm{g} / \mathrm{ml} / 3$ jam yaitu pada tanaman hasil mutasi nomor 71 . Sebaliknya nilai serapan terendah pada kondisi $\mathrm{N}$ optimal yaitu mencapai $-8.4 \mu \mathrm{g} / \mathrm{ml} / 3$ jam yaitu pada tanaman padi hasil mutasi dengan nomor 40, sedangkan nilai terendah serapan ammonium pada kondisi $\mathrm{N}$ sub optimal hanya mencapai $-0.4 \mu \mathrm{g} / \mathrm{ml} / 3$ jam yaitu pada tanaman hasil mutasi nomor 102. Hasil tersebut menunjukkan bahwa semakin banyak kadar $\mathrm{N}$ yang diberikan pada tanaman, maka serapan $\mathrm{N}$ (ammonium) juga akan semakin besar, sebaliknya pemberian $\mathrm{N}$ dengan kadar yang rendah, maka serapan $\mathrm{N}$ (ammonium) juga akan rendah. Hal ini sesuai dengan hasil penelitian Hasanudin dkk, (2006), yang menerangkan bahwa peningkatan kadar N yang diberikan akan diikuti dengan peningkatan serapan N. Soepardi (1983) juga menyatakan bahwa serapan unsur hara oleh tanaman sangat dipengaruhi oleh kadar serta ketersediaan hara yang terdapat dalam tanah. Serapan nitrogen yang meningkat berdampak kebutuhan nitrogen pada fase vegetatif tanaman akan tercukupi, sehingga dapat meningkatkan biomasa tanaman (Irwan dkk., 2005).

Berdasarkan hasil penelitian mengenai pengaruh hasil mutasi secara kimia terhadap peningkatkan kemampuan tanaman padi dalam menyerap unsur $\mathrm{N}$ pada kondisi optimal dan sub optimal kandungan $\mathrm{N}$ dalam media, diperoleh bahwa tanaman hasil dari 
benih yang dimutasi memiliki serapan $\mathrm{N}$ yang lebih baik, terutama serapan ion ammonium. Tanaman hasil benih yang dimutasi memiliki nilai serapan ammonium yang tinggi, bahkan ada yang mencapai $10.3 \mu \mathrm{g} / \mathrm{ml} / 3$ jam yaitu pada tanaman nomor 37 dengan kondisi $\mathrm{N}$ optimal, sedangkan yang tidak dimutasi nilai serapan tertingginya adalah 2.65 $\mu \mathrm{g} / \mathrm{ml} / 3$ jam, yaitu pada tanaman nomor 57. Nilai serapan ammonium dengan kondisi $\mathrm{N}$ sub optimal, nilainya lebih rendah lagi meskipun sama-sama dimutasi, yaitu nilai tertingginya hanya $1.23 \mu \mathrm{g} / \mathrm{ml} / 3 \mathrm{jam}$, yang terdapat pada tanaman padi nomor 71 .

Serapan ammonium pada penelitian ini diukur dari selisih kandungan ammonium pada pengamatan pertama dengan kandungan ammonium pada pengamatan kedua. Berkurangnya serapan ammonium pada pengamatan kedua dapat terjadi karena pemanfaatan oleh tanaman serta adanya perubahan bentuk amonium menjadi bentuk senyawa nitrogen lainnya (Azis dan Kurnia, 2015). Purwanto (2007) menjelaskan bahwa adanya penurunan ammonium dalam tanah, maka akan meningkatkan konsentrasi nitrat dalam tanah karena terjadi proses transformasi ammonium menjadi nitrat. Perubahan bentuk nitrogen tersebut dapat terjadi akibat aktifitas dari mikroorganisme yang mampu merubah amonium menjadi nitrat, yaitu pada proses nitrifikasi. Penurunan kandungan ammonium pada pengamatan kedua juga dapat disebabkan oleh proses immobilisasi. Immobilisasi ini terkait dengan proses dikonsumsinya unsur nitrat dan ammonium oleh organisme tanah, sehingga menjadi tidak dapat dikonsumsi oleh tanaman.

Penurunan nitrogen ammonium juga dapat terjadi akibat proses pencucian atau leaching. Akan tetapi persentase hilangnya ammonium akibat proses pencucian pada tanah lebih sedikit apabila dibandingkan dengan nitrat, karena ammonium teradsorpsi pada kompleks pertukaran kation. Kehilangan nitrogen melalui pencucian ini terutama terjadi pada tanah yang bertekstur kasar dengan kapasitas tukar kation yang rendah. Pada tanah yang sumber muatan negatif utamanya dari senyawa organik dibanding anorganik, ion ammonium juga dapat tercuci melalui air perkolasi (De Datta, 1981).

Proses volatilisasi juga dapat menurunkan kandungan ammonium dalam tanah, dimana volatilisasi termasuk proses transformasi $\mathrm{NH}_{4}{ }^{+}$menjadi $\mathrm{NH}_{3}$ yang selanjutnya akan menguap ke atmosfer apabila tanah kering. Laju proses kehilangan nitrogen secara volatilisasi semakin meningkat pada kondisi tanah yang memiliki $\mathrm{pH}$ tanah tinggi dan tanah yang mudah kehilangan air, misalnya pada kondisi panas dan berangin. De Datta (1981) menerangkan bahwa ketika keadaan $\mathrm{pH}$ lebih rendah dari $\mathrm{pH}$ netral, maka hilangnya nitrogen melalui volatilisasi relatif sangat kecil, sedangkan pada $\mathrm{pH}$ yang tinggi hilangnya nitrogen akan meningkat dan dapat mempengaruhi produksi. Proses 
volatilisasi ini dapat terjadi akibat penguapan melalui sistem kapiler tanah, yaitu $\mathrm{NH}_{4}{ }^{+}$ yang terlarut dalam air akan bergerak ke lapisan atas dan hilang melalui proses evaporasi.

Kandungan ammonium juga mengalami peningkatan pada pengamatan kedua, disamping mengalami penurunan. Peningkatan ammonium tersebut dapat disebabkan oleh proses fiksasi $\mathrm{N}$ dan minerelisasi $\mathrm{N}$, khususnya amonifikasi N. Fiksasi $\mathrm{N}$ merupakan proses yang menggabungkan nitrogen bebas dengan unsur lain secara kimia yang disebut dengan penambatan nitrogen. Salah satu caranya melalui kegiatan organisme bersimbiosis yang dapat mengubah nitrogen dari atmosfer menjadi ammonia. Pemfiksasi $\mathrm{N}_{2}$ utama adalah bakteri tanah yang hidup bebas serta Cyanobakteri (ganggang hijaubiru) yang hidup bebas pada permukaan tanah maupun dalam air. Fiksasi nitrogen secara biologis terjadi ketika nitrogen di atmosfer diubah menjadi amonia melalui enzim bakteri yang disebut nitrogenase. Meskipun ammonia adalah produk langsung dari reaksi ini, maka dengan cepat akan terionisasi menjadi ammonium. Kemampuan penambatan $\mathrm{N}$ secara biologis dalam mengkonversi $\mathrm{N}_{2}$ menjadi $\mathrm{N}$ organik sangat substansial, dimana lebih dari cukup untuk mempertahankan kebutuhan $\mathrm{N}$ serta mengganti $\mathrm{N}$ yang hilang (Vitousek et al., 2002).

Mineralisasi $\mathrm{N}$ juga dapat meningkatkan kandungan ammonium dalam tanah. Mineralisasi merupakan proses yang dilakukan oleh mikroba untuk menguraikan $\mathrm{N}$ organik dari material organik, kotoran hewan, dan sisa tanaman menjadi bentuk ammonium. Mineralisasi ini termasuk proses biologis, sehingga kecepatan dan kadar mineralisasinya sangat bervariasi tergantung kelembaban tanah, suhu tanah, dan jumlah oksigen yang terkandung di dalam tanah. Proses mineralisasi hanya dapat terjadi ketika berada pada kondisi tanah yang hangat $\left(20-35^{\circ} \mathrm{C}\right)$, kondisi tanah yang beraerasi, serta memiliki kelembaban yang baik. Menurut Havlin et al., (1999), proses mineralisasi ini melibatkan dua reaksi, yaitu reaksi aminisasi serta amonifikasi yang terjadi melalui aktivitas mikroorganisme heterotrofik. Proses ammonifikasi ini merupakan proses perombakan senyawa $\mathrm{N}$ organik secara enzimatik menjadi ammonium. Beberapa enzim yang terlibat adalah peptidase, khitinase, proteinase, protease, ketobiase. lisozim, endonuklease, eksonuklease, serta urease.

\section{KESIMPULAN}

\section{Kesimpulan}

Mutasi menghasilkan keragaman genetik dan menyebabkan terjadinya perubahan fenotipik pada tanaman padi yang termutasi. Berdasarkan hasil penelitian mengenai pengaruh hasil mutasi secara kimia menggunakan EMS terhadap peningkatkan 
kemampuan tanaman padi dalam menyerap unsur $\mathrm{N}$ pada kondisi optimal dan sub optimal kandungan $\mathrm{N}$ dalam media, diperoleh bahwa tanaman hasil dari benih yang dimutasi memiliki serapan $\mathrm{N}$ yang lebih tinggi, terutama serapan ion ammonium. Tanaman hasil benih yang dimutasi memiliki nilai serapan $\mathrm{N}$ ammonium yang tinggi dibandingkan dengan lainnya, yaitu pada tanaman nomor 37 dengan kondisi $\mathrm{N}$ optimal yang mencapai $10.3 \mu \mathrm{g} / \mathrm{ml}$ dan pada kondisi $\mathrm{N}$ sub optimal mencapai $1.23 \mu \mathrm{g} / \mathrm{ml}$ yang terdapat pada tanaman nomor 71 .

\section{Saran}

Perlu dilakukan kegiatan pembersihan terhadap media tanam padi ketika terdapat tanaman Azolla pinnata dan lumut kerak di dalamnya supaya tidak mempengaruhi kandungan $\mathrm{N}$ dalam tanah dan serapan $\mathrm{N}$ oleh tanaman, baik itu nitrat maupun ammonium.

\section{DAFTAR PUSTAKA}

Adhikary, S.P. and B. Pattanaik. 2006. Cyanobacterial Biofertilizers for Rice: Present Status and Future Prospects. dalam: Rai, M. K. (ed.). Handbook of Microbial Biofertilizers. New York: Haworth Press.

Adiwiganda, Y.T. and A. Wild. 1989. Measurement of N Loss from Soil in The Form of $\mathrm{N}_{2} \mathrm{O}$ Gas. Crop Science, 4(1): 45-50.

Afandie. 2002. Menuju Pemupukan Berimbang Guna Meningkatkan Jumlah dan Mutu Hasil Pertanian. Jakarta: Dit. Penyuluhan Tanaman Pangan, Dir. Jen. Pert. Tan. Pangan, Deptan.

Amir, L., A.P. Sari, St. F. Hiola, dan O. Jumadi. 2012. Ketersediaan Nitrogen Tanah dan Pertumbuhan Tanaman Bayam (Amaranthus tricolor L.) yang Diperlakukan dengan Pemberian Pupuk Kompos Azolla. Sainsmat, 1(2): 167-180.

Azis, A.A. dan N. Kurnia. 2015. Kandungan Amonium dan Nitrat Tanah pada Budidaya Bayam Putih dengan Menggunakan Pupuk Urin Manusia. Bionature, 16(2): 8690.

Baethgen, W.E. and M.M. Alley. 1989. A Manual Colorimetric Procedure for Measuring Ammonium Nitrogen in Soil and Plant Kjeldahl Digests. Commun. Soil Sci. Plant Anal, 20 (9,10): 961-969.

Bouguyon E., A. Gojon, and P. Nacry. 2012. Nitrate Sensing and Signaling in Plants. Seminars in Cell Dev Biol, 23: 648-654.

Cataldo, D.A., M. Haroon, L.E. Scharader, and U.L. Youngs. 1975. Rapid Calorimetric Ditermination of Nitrate in Plant Tissue by Nitration of Salycilic Acid. Soil Science and Plant Analysis, 6(1): 71-80. 
D’Haene, K., E. Moreels, S. De Neve, B.C. Daguilar, P. Boeckx, G. Hofman, and O.V. Cleemput. 2003. Soil Properties Influencing the Denitrification Potential of Flemish Agricultural Soils. Biol Fertile Soils, 38: 358-366.

De Datta, S.K. 1981. Principles and Practices of Rice Production. New York: John Wiley \& Sons, Inc.

Engelstad, O.P. 1997. Teknologi dan Penggunaan Pupuk. Yogyakarta: Gadjah Mada University Press.

Gardner, F.P., R.B. Pearce, and R.L. Mitchell. 1991. Fisiologi Tanaman Budidaya. Terj. dari Physiology of Crop Plants, oleh Susilo, H. Jakarta: UI-Press.

Graham, L.E. and L.W. Wilcox. 2000. Algae. New Jersey: Prentice-Hall, Inc. Upper Saddle River.

Halvin, J.L., S.M. Tisdale, W.L. Nelson, and J.D. Beaton. 1999. Soil Fertility and Fertilizer. An Introduction to Nutrient Management. Prentice Hall, Inc.

Handayanto dan Hairiah. 2009. Biologi Tanah Landasan Pengelolahan Tanah Sehat. Malang: Pustaka Adipura.

Hardjowigeno, S. 2010. Ilmu Tanah. Jakarta: CV. Akademika Presindo.

Hasanudindan, B.G.M. dan Y. Indriyani. 2006. Peran Pupuk N dan P Terhadap Serapan $\mathrm{N}$, Efisiensi N, dan Hasil Tanaman Jahe di Bawah Tegakan Tanaman Karet. Ilmu-Ilmu Pertanian Indonesia, 8(1): 61-68.

Hillel, D. 1980. Fundamentals of Soil Physics. Academica Press.

Irwan, A.W., A. Wahyudin, dan Farida. 2005. Pengaruh Dosis Kascing dan Bioaktivator Terhadap Pertumbuhan dan Hasil Tanaman Sawi (Brassica juncea L.) yang Dibudidayakan secara Organik. Kultivasi, 4(2): 136-140.

Jamilah dan N. Safridar. 2012. Pengaruh Dosis Urea, Arang Aktif dan Zeolit Terhadap Pertumbuhan dan Hasil Padi Sawah (Oryza sativa L.). Agrista, 16(3): 153-159.

Kaya, E. 2013. Pengaruh Kompos Jerami dan Pupuk NPK Terhadap N-Tersedia Tanah, Serapan-N, Pertumbuhan, dan Hasil Padi Sawah (Oryza sativa L.). Prosiding FMIPA Universitas Pattimura.

Krock, T., J. Alkamper, and I. Watanabe. 1988. Effect of An Azolla Cover in The Condition of Flood Water. Agriculture and Crop, 161: 185-189.

Leiwakabessy, F.M. dan A. Sutandi. 1998. Diktat Kuliah Pupuk dan Pemupukan. Bogor: IPB.

Li, R., P. Guo, M. Baum, S. Grando, and S. Ceccarelli. 2006. Evaluation of Chlorophyll Content and Fluorescence Parameters as Indicators of Drought Tolerance in Barley. Agricultural Sciences, 5(10): 751-757.

Lintang, A., D. Indradewa, dan E. Ambarwati. 2012. Pertumbuhan, Hasil dan Kualitas Pucuk The (Camellia sinensis (L.) Kuntze) di Berbagai Tinggi Tempat. Yogyakarta: UGM.

López-Arredondo, D.L., M.A. Leyva-González, F. Alatorre-Cobos, and L. HerreraEstrella. 2013. Biotechnology of Nutrient Uptake and Assimilation in Plants. Dev. Biol, 57: 595-610.

Mapegau. 2007. Pengaruh Pupuk Nitrogen Terhadap Pertumbuhan dan Hasil Tanaman Kacang Hijau. Agripura, 3(2): 401-410. 
Matsunami, M., T. Matsunami, K. Kon, A. Ogawa, I. Kodama, and M. Kokubun. 2013. Genotypic Variation in Nitrogen Uptake During Early Growthamong Rice Cultivars Under Different Soil Moisture Regimes. Plant Production Science, 16(3): 238-246.

Meliala, J.H.S., N. Basuki, dan A. Seogianto. 2016. Pengaruh Iradiasi Sinar Gamma Terhadap Perubahan Fenotipik Tanaman Padi Gogo (Oryza sativa L.). Produksi Tanaman, 4(7): 585-594.

Mengel, K. and E.A. Kirkby. 1982. Principles of Plant Nutrition 3rd Edition International Potash Institute. Warblaufen-Bern Switzerland.

Mukhlis dan Fauzi. 2003. Pergerakan Unsur Hara $N$ dalam Tanah. Digital Library. Fakultas Pertanian, Universitas Sumatera Utara.

Mulyanto, F.D., N.E. Suminarti, dan Sudiarso. 2018. Respon Tanaman Kacang Tanah (Arachis hypogaea L.) pada Berbagai Aplikasi Pupuk N dan Kompos Azolla. Produksi Tanaman, 6(5): 791-800.

Novizan. 2005. Petunjuk Pemupukan yang Efektif. Jakarta: Agromedia Pustaka.

Peterson, T.A., T.M. Blackmer, D.D. Francis, and J.S. Schepers. 1996. Using Chlorophyll Meter to Improve N Management. Lincoln: University of Nebraska.

Pheng, S., G.S. Khush, P. Virk, Q. Tang, and Y. Zou. 2008. Progress in Ideotype Breeding to Increase Rice Yield Potential. Field Crop Research, 108(3): 32-38.

Purwanto, B, H. 2007. Recovery Rates of Nitrogen Fertilizer Applied of Peat Soils in Different Characteristics and Landuse. Ilmu Tanah dan Lingkungan, 7(2), 117121.

Putra, D.F., Soenaryo, dan S.Y. Tyasmoro. 2013. Pengaruh Pemberian Berbagai Bentuk Azolla dan Pupuk $\mathrm{N}$ terhadap Pertumbuhan dan Hasil Tanaman Jagung Manis (Zea mays Var. Saccharata). Produksi Tanaman, 1(4): 353-359.

Salisbury, F.B. and Ros, Cleon W. 1995. Fisiologi Tumbuhan, Jilid 2. Bandung: ITB.

Santamaria, P. 2006. Nitrate in Vegetables: Toxicity, Content, Intake, and EC Regulation. Food and Agriculture, 86: 10-17.

Saragih, B. 2001. Keynote Address Ministers of Agriculture Government of Indonesia. $2^{\text {nd }}$ National Workshop On Strengthening The Development And Use Of Hibrid Rice In Indonesia. 1:10.

Setyani, Y.H., S. Anwar, dan W. Slamet. 2013. Kataristik Fotosintetik dan Serapan Fosfor Hijauan Alfalia (Medicago sativa) pada Tinggi Pemotongan dan Pemupukan Nitrogen yang Berbeda. Animal Agriculture, 1(2): 86-96.

Soepardi, G.1983. Sifat dan Ciri Tanah. Bogor: IPB Pers.

Subramani, S.A., C. Narayan, S. Srinivasan, dan B. Chandrasekharam. 1980. Proccedings of FAI Seminar on Fertilizers in India in Eightees. India: Tamil Nadu Agriculture University.

Sugimoto, H., K. Kusumi, Y. Tozawa, J. Yazaki, N. Kishimoto, S. Kikuchi, and K. Iba. 2004. The Virescent-2 Mutation Inhibition Translation of Plastid Transcripts for The Plastic Genetic System at An Early Stage of Chloroplast Differentiation. Plant Cell Physiol, 45(8): 185-210.

Sumenda, L., H.L. Rampe, dan F.R. Mantiri. 2011. Analisis Kandungan Klorofil Daun Mangga (Mangifera indica L.) pada Tingkat Perkembangan Daun yang Berbeda. Biologos, 1(1): 20-24. 
Taiz, L. and E. Zeiger. 2002. Plant physiology. 3rd Ed. USA: Sinauer Associates.

Tillman, R.W. and D. R. Scotter. 1991. Movement of Solute Associated with Intermittent Soil Water Flow II. Nitrogen and Cation. Soil Research, 29(2): 185-196.

Vaishampayan, A., R.P. Sinha, D.P. Hader, T. Dey, A K. Gupta, U. Bhan, and A.L. Rao. 2001. Cyanobacterial Biofertilizers in Rice Agriculture. Botanical Review, 67(4): 453-516.

Vitousek, P.M., K. Cassman, C. Cleveland, T. Crews, C.B. Field, N.B. Grimm, R.W. Howarth, R. Marino, L. Martinelli, E.B. Rastetter, and J.I. Sprent. 2002. Towards an Ecological Understanding of Biological Nitrogen Fixation. Biogeochemistry, 57/58: 1 - 45.

Wei, F.J., G. Droc, E. Guiderdoni, and Y.C. Hsing. 2013. International Consortium of Rice Mutagenesis Resources and Beyond. Rice, 6: 39.

Wild, A. 1981. Mass Flow and Diffusion in D.J. Grreenland and M.H.B. Hayes (eds). The Chemistry of Soil Processes. New York: John Wiley \& Sons.

Yoshida, S., A.D. Forno, J.H. Cock, and K.A. Gomez. 1976. Laboratory Manual for Physiological Studies of Rice. IRRI, Los Banos, Philippines. 